\section{EL CENTRO COSMOPOLITA DE TRABAJADORES: UN ESPACIO DE REFERENCIA DEL MOVIMIENTO OBRERO EN EL NORTE ARGENTINO EN LOS UMBRALES DEL SIGLO XX}

\author{
VANESA TEITELBAUM
}

Vanesa Teitelbaum es Investigadora del CONICET con sede en el Instituto Superior de Estudios Sociales de la Universidad Nacional de Tucumán.

e-mail: vteitel@yahoo.com

\section{Resumen}

El propósito de este artículo es estudiar las prácticas políticas, de protesta y culturales desarrolladas a partir de un ámbito central del universo laboral tucumano de finales del siglo XIX y comienzos del XX: el Centro Cosmopolita de Trabajadores. Para ello, comenzaremos con una breve descripción en torno a la composición del centro y sus primeras incursiones en política electoral. En segundo lugar, analizaremos las principales protestas que encabezó el centro obrero en la época. El artículo incluye también un examen de las actividades de recreación y cultura, como veladas y conferencias, para finalmente sugerir algunas consideraciones en torno a la conformación de una cultura obrera.
Una versión preliminar de este trabajo se presentó en la Conferencia de Acreditación en la Facultad de Humanidades y Ciencias de la Educación, Universidad Nacional de la Plata, el día 8 de julio de 2010. La autora agradece a Ángela Oyhandy sus impulsos para la realización de esa conferencia, que fue dedicada a Ricardo Falcón.

\section{Summary}

The purpose of this paper is to study the political practices, protest and culture developed from a central institution in the world of Tucumán work of the late nineteenth and early twentieth: the Cosmopolitan Workers Center. We will start with a brief description about the composition of the center and its first forays into electoral politics. Secondly, we discuss the major protests that led the workers' center at the time. The article also includes a review of recreational and cultural activities, such as evenings and conferences, and finally suggest some considerations about the formation of a working-class culture. 